\title{
JAIME NATAN EISIG: a way to be followed
}

Zaterka S. Jaime Natan Eisig: A way to be followed. Arq Gastroenterol. 2016;53(2): 58-9.

I met Jaime when he was still very young, but our closer relationship began at the end of the decade of 70 , or early 80 when I invite him to work with me at the Gastroenterology Department of Hospital das Clínicas da Faculdade de Medicina da Universidade de São Paulo. I was chief of the Group of Stomach and Duodenum, being the service headed by Agostinho Bettarello. Since that occasion our lives were a continuum of work and friendship.

Born in 1950, February, 23, Jaime graduated in medicine at the University of Mogi das Cruzes in the 1973. On 1979, Jaime, get married with Regina Jalen; this union born two beautiful girls, Tatiana and Vivian. Jaime has always been a devoted husband and loving father, he always showed dedication and affection to our specialty and to young doctors, interns and residents.

In our outpatient clinic group, Jaime was always ready to discuss the cases with the young doctors, to guide on clinical reasoning and treatment. Was also a great researcher. His master's thesis presented in 1991 was "Hansen's Disease and the Digestive Tract: clinical study and stomach secretory profile in basal conditions and after stimulation by pentagastrin". In 2003 reached his $\mathrm{PhD}$ degree, featuring the work "Recurrence of Helicobacter pylori in patients with duodenal ulcer: clinical, endoscopic, histological and genotyping aspects: 10 years follow-up". On both occasions was approved with honors.

Excellent speaker and taught, was often invited for lectures in all Brazil as well as abroad. There were hundreds. As a researcher he devoted himself to themes by which had special interest: gastric secretion, gastroduodenal ulcer, Helicobacter pylori and gastroesophageal reflux disease. He published more than 80 papers, many of which in international magazines.

But it's not just in teaching and research that Jaime stood out. His interest and dedication to gastroenterology was intense. In 1996 the late Prof. Luiz Guilherme Lyra called Jaime for Specialists Committee of Brazilian Federation of Gastroenterology (FBG): it was the beginning of a long and productive collaboration with our main entity.

In the biennium 1998-2000, attending the request of the President Waldomiro Dantas, Jaime became the Chairman of that Committee. During three consecutive administrations, from 2002 to 2008 he held the position of Executive Secretary of the FBG.

During the management of Frederico Magalhães (2006-2008) São Paulo hosted the VII Brazilian Digestive Diseases Week. Member of the Organizing Committee, Jaime played a key role in the great success of the event. So, with extensive experience, it was no surprise he was elected President in 2008, a position he held until 2010. Numerous were the accomplishments during his administration. Let's remember only a few:

\section{Young Gastroenterologist program implementation}

Designed by our colleague Odery Ramos from Curitiba, it offered to young people interested in Gastroenterology the opportunity to access and participate in the society events our, with numerous perks such as exemption from payment of the annuity, substantial reduction of the registration fee in Congress, free access to online classes and to the library of specialty magazines. Besides, the FBG stimulated events from young gastroenterologists.

\section{Trans-Meeting course}

Were 18 courses with 2,800 people monthly access average. The presentation was modified allowing the speakers and those who attended had interactivity, which made it more dynamic.

\section{Headquarters FBG remodeling}

\section{60 years FBG Meeting}

To celebrate this festive day date (2009, October, 23 ), FBG hosted a dinner at the Blue Tree Hotels Morumbi, which was attended by about 150 guests. Were honored for valuable contributions, true icons of our specialty as: Joffre Rezende, Nereu de Almeida, José de Souza Meirelles Filho, Henrique Walter Pinotti, among others.

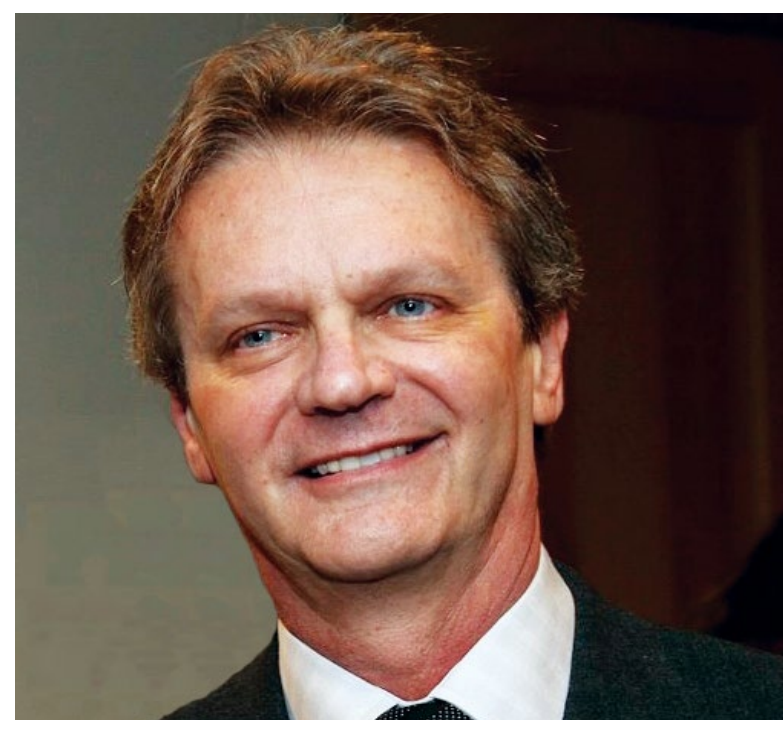

Dr. Jaime Natan Eisig 


\section{IX Brazilian Digestive Week, held in Florianopolis}

\section{Train the Trainers}

This program of the World Gastroenterology Organisation with the purpose to train teachers to better transmit knowledge to students was held in Brazil in Angra dos Reis. Attended 23 Brazilian and 21 foreign participants.

\section{Textbook of Gastroenterology: trom graduation to graduate}

Editors: Schlioma Zaterka and Jaime Natan Eisig. Released during the XI Brazilian Week of Gastroenterology (Florianópolis), had the Edition quickly sold out. The Second Edition, with the support of our current President, Prof. Maria do Carmo Friche Passos, was completed and will be released in July of this year at the second Congress of Functional Digestive Disease and First of Microbiota to be held in the city of Gramado, RS. Jaime was tireless in realization of this work. Unfortunately, he will not be present in its release.

Jaime was also one of the founders of the Brazilian Nucleus for the Helicobacter pylori study of (1994, Porto Alegre) performing the function of Secretary in the current Executive Board (President Luis Gonzaga Vaz Coelho).
Althoug worring about his disease, and feeling a little weak he did not hesitate accepting another challenge, when invited by Maria do Carmo to fill the position of Communications and Events Director from FBG.

Jaime Natan Eisig, ethical and caring physician, assiduous master, conscious researcher, always worring about associative activities, devoted father, husband and grandfather of a beautiful 18 months old boy (Theo) and major developer of FBG.

Prematurely, on 2016, 22, February, Jaime passed away. A sad coincidence, his funeral happened on the same day of his birth day: Feb 23rd.

Thank you for everything you gave us Jaime. Thank you for the moments of frustration, anguish, difficulties faced together and thank to you, were overcome. Thank you Jaime for giving all moments of great joy and for so many goals achieved. You are an example to be followed by future generations.

* Honorary President of the Brazilian Nucleus for the Helicobacter pylori Study (Núcleo Brasileiro para Estudo do Helicobacter pylori). Ex head of Stomach and Duodenum Group of Gastroenterology Department. Hospital das Clinicas da Faculdade de Medicina da USP. 